\title{
Profil hematologi anjing lokal di wilayah endemik rabies
}

\author{
Agus Wijaya $^{1, *}$, Ronald Tarigan ${ }^{2}$, Koekoeh Santoso ${ }^{2}$, Yusuf Ridwan ${ }^{3}$, Etih Sudarnika $^{3}$, \\ Abdul Zahid Ilyas ${ }^{3}$, Deny Widaya Lukman ${ }^{3}$, Ardilasunu Wicaksono ${ }^{3}$, Arifin Budiman Nugraha ${ }^{3}$, \\ Usamah Afiff $^{3}$, Sri Murtini ${ }^{3}$, Edi Sukmawinata ${ }^{3}$, Annisa Madyanti Geminastiti Parampasi ${ }^{4}$ \\ ${ }^{1}$ Departemen Klinik Reproduksi dan Patologi, Fakultas Kedokteran Hewan, Institut Pertanian Bogor, Bogor \\ ${ }^{2}$ Departemen Anatomi Fisiologi dan Farmakologi, Fakultas Kedokteran Hewan, Institut Pertanian Bogor, Bogor \\ ${ }^{3}$ Departemen Ilmu Penyakit Hewan, Fakultas Kedokteran Hewan, Institut Pertanian Bogor, Bogor \\ ${ }^{4}$ Program Sarjana Kedokteran Hewan, Fakultas Kedokteran Hewan, Institut Pertanian Bogor, Bogor
}

\begin{abstract}
ABSTRAK: Provinsi Jawa Barat merupakan satu dari 24 provinsi di Indonesia yang dilaporkan belum bebas rabies. Usaha pembebasan wilayah Jawa Barat dari penyakit rabies sangat strategis mengingat posisi Jawa Barat berada di antara daerah bebas rabies. Jampang Tengah menjadi salah satu kecamatan di Sukabumi yang pada tahun 2016 dilaporkan telah terjadi 13 kasus gigitan rabies. Penelitian ini menggunakan 81 sampel darah anjing lokal yang dikoleksi dari 6 desa di kecamatan Jampang Tengah dan diperiksa dengan menggunakan alat Rayto ${ }^{\circledR}$ hematology analyzer. Parameter profil hematologi dikelompokkan berdasarkan perbedaan umur dan jenis kelamin anjing. Hasil pemeriksaan hematologi secara umum berdasarkan umur menunjukkan nilai rataan yang lebih besar pada anjing lokal umur $\geq 1$ tahun dan konsentrasi leukosit menunjukkan nilai statistik yang signifikan berbeda $(\mathrm{p}<0.05)$. Berdasarkan jenis kelamin, nilai rataan parameter hematologi secara umum lebih tinggi pada anjing lokal betina dan adanya perbedaan signifikan $(\mathrm{p}<0.05)$ pada konsentrasi leukosit dan granulosit.

Kata kunci:

anjing lokal, jenis kelamin, hematologi, umur, wilayah endemik rabies
\end{abstract}

\section{- PENDAHULUAN}

Beberapa penyakit infeksius pada anjing seperti Rabies, Leptospi-rosis, Leismaniosis, dan Toxocariasis bersifat zoonotis pada manusia. Penyebab penyakit Encephalitis Rabies adalah virus golongan Lyssa virus dan famili Rhabdoviridae (CDC, 2011). Metode diagnosa untuk isolasi virus Rabies dilakukan dengan menyuntikkan suspensi otak pada mencit atau inokulasi pada biakan sel neuroblastoma. Identitas virus ditentukan dengan FAT, uji virus netralisasi atau pewarnaa (Bourhy et al, 1989). Strategi pembebasan wilayah dari penyakit Rabies dapat dikategorikan menjadi tiga yaitu, lokasi tertular, lokasi terancam dan lokasi bebas kasus (Ditjen PKH Deptan, 1997). Pemeriksaan hematologi merupakan salah satu upaya pemantauan status kesehatan, mengevaluasi, serta untuk mendiagnosa penyakit.

\section{- BAHAN DAN METODE}

Sampel darah diambil pada bulan Juli-Oktober 2016 dan diperiksa di Fakultas Kedokteran Hewan (FKH), Institut Pertanian Bogor (IPB) menggunakan hematology analyzer (Rayto ${ }^{\circledR}$, Rayto Life and Analytical Sciences Co. Ltd, Japan). Sampel darah anjing lokal berpemilik berjumlah 81 sampel dari 6 desa di kecamatan Jampang Tengah (Jampang Tengah, Bantar Panjang, Bojong Jengkol, Sindang Resmi, Pada Beunghar, Tanjung Sari). Sampel darah sebanyak 2 $\mathrm{mL}$ diambil dan dimasukkan ke dalam tabung vakum
EDTA. Pengamatan yang dilakukan meliputi perbedaan parameter hematologi berdasarkan umur dan jenis kelamin.

\section{- HASIL DAN PEMBAHASAN}

Konsentrasi leukosit pada anjing lokal Jampang Tengah dengan perbedaan umur menunjukkan nilai statistik yang signifikan berbeda $(\mathrm{p}<0.05) \quad($ Tabel 1). Nilai rataan parameter hematologi lebih tinggi pada anjing berumur $\geq 1$ tahun. Nilai hematologi pada anjing dewasa lebih tinggi pada parameter eritrosit, hematokrit, hemoglobin, dan indeks eritrosit (Olayemi et al. 2009).

Rataan parameter hematologi pada konsentrasi leukosit berdasarkan kategori umur berbeda signifikan $(\mathrm{p}<0.05)$. Leukosit berfungsi dalam mekanisme pertahanan tubuh terhadap infeksi penyakit. Faktor lain berupa stres juga menyebabkan peningkatan sintesis dan pelepasan glukokortikoid dan katekolamin oleh kelenjar adrenal ke dalam sirkulasi (Kanczkowski et al. 2016).

Hasil pemeriksaan hematologi menunjukkan nilai rataan yang lebih tinggi pada anjing lokal betina (Tabel 2). Rataan parameter hematologi yang lebih tinggi tersebut diduga

Diterima: 29-09-2017 | Direvisi: 09-11-2017 | Disetujui: 14-11-2017

(C) 2018 CC-BY-SA. Ini adalah artikel Open Access yang didistribusikan berdasarkan ketentuan dari Creative Commons Attribution ShareAlike 4.0 International License (https://creativecommons.org/licenses/by-sa/4.0/). 
dipengaruhi oleh adanya kadar Type 5 Acid Phosphatase (ACP 5) atau uteroferrin. Berdasarkan penelitian OrtegaPacheco et al. (2007), bulan Juli-Oktober adalah waktu dengan kondisi kejadian ovulasi yang tinggi di iklim tropis. Selama ovulasi, sekresi hormon estrogen tinggi dalam sirkulasi (Mahendro et al. 1997). Menurut Mierzejewska et al. (2015), hormon ini mempunyai reseptor ER-2ß yang banyak terakumulasi di haemopoietic stem progenitor cells (HSPCs).

Tabel 1 Rataan parameter hematologi berdasarkan kategori umur

\begin{tabular}{|lccc|}
\hline \multirow{2}{*}{ Parameter } & \multicolumn{3}{c|}{ Rata-rata \pm SD } \\
\cline { 2 - 4 } & $\begin{array}{c}\text { Pre Pubertas } \\
\leq 1 \text { Tahun } \\
(\mathrm{n}=51)\end{array}$ & $\begin{array}{c}\text { Pubertas } \\
\geq 1 \text { Tahun } \\
(\mathrm{n}=30)\end{array}$ & $\begin{array}{c}\text { Nilai } \\
\text { Referensi }\end{array}$ \\
\hline Hemoglobin $(\mathrm{g} / \mathrm{dl})$ & $8.13 \pm 1.81$ & $8.77 \pm 2.15$ & $12-19^{*}$ \\
Hematokrit $(\%)$ & $31.29 \pm 4.49$ & $32.35 \pm 5.70$ & $35-37^{*}$ \\
Eritrosit $\left(\mathrm{x} 10^{6} / \mu \mathrm{l}\right)$ & $5.60 \pm 0.86$ & $5.67 \pm 0.96$ & $5-7.9^{*}$ \\
MCV (fl) & $56.47 \pm 3.49$ & $57.17 \pm 3.25$ & $65-80^{* *}$ \\
MCH $(\mathrm{pg})$ & $14.52 \pm 2.38$ & $15.35 \pm 2.31$ & $21-36^{*}$ \\
MCHC $(\mathrm{g} / \mathrm{dl})$ & $25.64 \pm 3.34$ & $26.89 \pm 3.59$ & $32-36^{*}$ \\
Leukosit $\left(\mathrm{x} 10^{3} / \mu \mathrm{l}\right)$ & $16.59 \pm 4.97^{\mathrm{a}}$ & $19.45 \pm 6.03^{\mathrm{b}}$ & $5.9-16.6^{* *}$ \\
Limfosit $(\%)$ & $3.73 \pm 1.75$ & $4.25 \pm 2.46$ & $8-38^{* *}$ \\
Granulosit $(\%)$ & $12.20 \pm 4.31$ & $13.44 \pm 5.71$ & - \\
\hline
\end{tabular}

Keterangan: Hasil analisis data menunjukkan ada perbedaan signifikan antar kategori umur yang diberi superscript $(\mathrm{p}<0.05)$

*Nilai menurut Latimer et al. (2003)

**Nilai menurut Jain (1986)

Adanya peningkatan yang berbeda signifikan $(\mathrm{p}<0.05)$ pada konsentrasi leukosit dan limfosit di antara kedua jenis kelamin dapat disebabkan karena adanya pengaruh hormon estrogen dan progesteron. Kedua hormon ini dimodulasi oleh amphiregulin (Areg) yang mampu menginduksi sitokin dan kemokin di kelenjar mamae pada anjing betina pubertas (Aupperlee et al. 2014). Selain itu, kedua kelompok menunjukkan keadaan anemia mikrositik-hipokromik.

Tabel 2 Rataan parameter hematologi berdasarkan jenis kelamin

\begin{tabular}{|lccc|}
\hline \multirow{2}{*}{ Parameter } & \multicolumn{3}{c|}{ Rata-rata \pm SD } \\
\cline { 2 - 4 } & $\begin{array}{c}\text { Jantan } \\
(\mathrm{n}=50)\end{array}$ & $\begin{array}{c}\text { Betina } \\
(\mathrm{n}=31)\end{array}$ & $\begin{array}{c}\text { Nilai } \\
\text { Referensi }\end{array}$ \\
\hline Hemoglobin $(\mathrm{g} / \mathrm{dl})$ & $8.28 \pm 1.89$ & $8.50 \pm 2.15$ & $12-19^{*}$ \\
Hematokrit $(\%)$ & $31.46 \pm 4.43$ & $32.29 \pm 5.88$ & $35-37^{*}$ \\
Eritrosit $\left(\mathrm{x} 10^{6} / \mu \mathrm{l}\right)$ & $5.57 \pm 0.76$ & $5.71 \pm 1.11$ & $5-7.9^{*}$ \\
$\mathrm{MCV}(\mathrm{fl})$ & $56.58 \pm 3.60$ & $57.05 \pm 3.87$ & $65-80^{* *}$ \\
$\mathrm{MCH}(\mathrm{pg})$ & $14.84 \pm 2.54$ & $14.81 \pm 2.20$ & $21-36^{*}$ \\
MCHC $(\mathrm{g} / \mathrm{dl})$ & $26.09 \pm 3.56$ & $26.09 \pm 3.51$ & $32-36^{*}$ \\
Leukosit $\left(\mathrm{x} 10^{3} / \mu \mathrm{l}\right)$ & $15.95 \pm 4.17^{\mathrm{a}}$ & $20.47 \pm 6.51^{\mathrm{b}}$ & $5.9-16.6^{* *}$ \\
Limfosit $(\%)$ & $3.65 \pm 1.96$ & $4.34 \pm 2.19$ & $8-38^{* *}$ \\
Granulosit $(\%)$ & $11.48 \pm 3.85^{\mathrm{a}}$ & $14.67 \pm 5.88^{\mathrm{b}}$ & - \\
\hline
\end{tabular}

Keterangan: Hasil analisis data menunjukkan ada perbedaan signifikan antar kategori umur yang diberi superscript $(\mathrm{p}<0.05)$

*Nilai menurut Latimer et al. (2003)

**Nilai menurut Jain (1986).

\section{- SIMPULAN}

Profil hematologi anjing lokal pada daerah endemik rabies menunjukkan nilai yang relatif lebih rendah. Faktor umur dan jenis kelamin memengaruhi konsentrasi leukosit. Sedangkan, parameter granulosit hanya dipengaruhi oleh faktor jenis kelamin.

\section{- INFORMASI PENULIS}

Penulis untuk Korespondensi

*AW: agwytk@gmail.com

Departemen Klinik, Reproduksi dan Patologi,

Fakultas Kedokteran Hewan, Institut Pertanian Bogor, Bogor

Jl. Agatis Kampus IPB Dramaga Bogor 16680

\section{- PUSTAKA ACUAN}

Aupperlee MD, Zhao Y, Tan YS, Leipprandt JR, Bennett J, Haslam SZ, Schwartz RC. 2014. Epidermal growth factor receptor (EGFR) signaling is a key mediator of hormone-induced leukocyte infiltration in the pubertal female mammary gland. Endocrinology. 155(6):2301-2313.

Bourhy H, Rollin PE, Vincent J, Sureau P. 1989. Comparative field evaluation of the fluorescent-antibody test, virus isolation from tissue culture, and enzyme immunodiagnosis for rapid laboratory diagnosis of rabies. Journal of Clinical Microbiology. 27(3):519-523.

CDC. 2011. The Rabies Virus. (http://www.cdc.gov/rabies/ transmission/virus.html), diakses pada 22 April 2011. Center for Disease Control and Prevention.

Ditjen PKH Deptan. 1997. Pedoman Teknis Pelaksanaan Pembebasan Rabies Terpadu di Indonesia, Direktorat Peternakan dan Kesehatan Hewan, Departemen Pertanian RI.

Jain NC. 1986. Normal values in blood of laboratory, fur-bearing, and miscellaneous zoo, domestic, and wild animals. In: Schalm's Veterinary Hematology. $4^{\text {th }}$ ed. Philadelphia (US): Lea \& Febiger.

Kanczkowski W, Mariko S, Stefan RB. 2016. Adrenal gland microenviroment and its involvement in the regulation of stress-induced hormone secretion during sepsis. Frontiers Endocrinology. 7:156.

Latimer KS, Mahaffet EA, Prasse KW. 2003. Veterinary laboratory medicine: clinical pathology. $4^{\text {th }}$ ed. Iowa (USA): Iowa State Press.

Mahendroo MS, Cala KM, Landrum CP, Russell DW. 1997. Fetal death in mice lacking 5alpha-reductase type 1 caused by estrogen excess. Molecular Endocrinology. 11(7):917-927.

Mierzejewska K, Borkowska S, Suszynska E, Suszynska M, Poniewierska-Baran A, Maj M, Pedziwiatr D, Adamiak M, Abdel-Latif A, Kakar SS, Ratajczak J. 2015. Hematopoietic stem/progenitor cells express several functional sex hormone receptors-novel evidence for a potential developmental link between hematopoiesis and primordial germ cells. Stem cells and development. 24(8):927-937.

Olayemi FO, Azeez IO, Ogunyemi A, Ighagbon FO. 2009. Study on erythrocyte values of the Nigerian indigenous dog. Folia Veterinaria. 53(2):65-67.

Ortega-Pacheco A, Segura-Correa JC, Jimenez-Coello M, Forsberg CL. 2007. Reproductive patterns and reproductive pathologies of stray bitches in the tropics. Theriogenology. 67(2):382-390. 